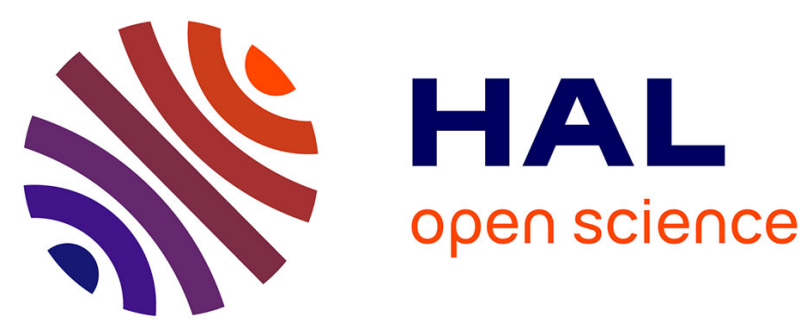

\title{
Effects of temperature, pressure and chemical compositions on the electrical conductivity of carbonated melts and its relationship with viscosity \\ David Sifré, Leila Hashim, Fabrice Gaillard
}

\section{- To cite this version:}

David Sifré, Leila Hashim, Fabrice Gaillard. Effects of temperature, pressure and chemical compositions on the electrical conductivity of carbonated melts and its relationship with viscosity. Chemical Geology, 2015, 418, pp.189-197. 10.1016/j.chemgeo.2014.09.022 . insu-01092350

HAL Id: insu-01092350

https://hal-insu.archives-ouvertes.fr/insu-01092350

Submitted on 8 Jan 2016

HAL is a multi-disciplinary open access archive for the deposit and dissemination of scientific research documents, whether they are published or not. The documents may come from teaching and research institutions in France or abroad, or from public or private research centers.
L'archive ouverte pluridisciplinaire HAL, est destinée au dépôt et à la diffusion de documents scientifiques de niveau recherche, publiés ou non, émanant des établissements d'enseignement et de recherche français ou étrangers, des laboratoires publics ou privés.

\section{(ㅇ)(1) $\$$}

Distributed under a Creative Commons Attribution - NonCommercial - NoDerivatives $\mid 4.0$ 


\title{
Effects of temperature, pressure and chemical compositions on the electrical conductivity of carbonated melts and its relationship with viscosity
}

\author{
David Sifré, Leïla Hashim, Fabrice Gaillard
}

\begin{abstract}
Carbonated melts constitute a key medium in the global deep carbon cycle: their impact on the geochemical signature of deep rocks is well studied because of their role as metasomatic agents in the deep mantle. However, their physical properties and in particular their electrical conductivity at high temperature and high pressure remain poorly constrained. In this study, we investigated the effect of chemical composition on the electrical conductivity of carbonated melts. We characterized this effect for various temperatures $\left(1000-1700{ }^{\circ} \mathrm{C}\right)$ and pressures (1 to $4 \mathrm{GPa})$. Measurements show a very high electrical conductivity $\left(>100 \mathrm{~S} \cdot \mathrm{m}^{-1}\right)$ with weak temperature, pressure and chemical composition dependence. Carbonated melts are five orders of magnitude more conductive than mantle olivine, and up to two orders of magnitude more conductive than basalts at similar $\mathrm{T}$ and $\mathrm{P}$. The electrical conductivity of molten carbonates follows an Arrhenius law and the different parameters were determined. A common activation volume was defined with $\Delta V=0.275 \mathrm{~J} / \mathrm{bar}$. As a result, we are able to calculate the electrical conductivity for larger temperature and pressure ranges for the melt compositions considered here. By combining the Nernst-Einstein and Eyring equations, a remarkably simple correlation was established between electrical conductivity and viscosity. The viscosity of carbonated melts, which is a key parameter defining the rate of metasomatic fluids flowing in the earth's mantle, can therefore be calculated as a function of pressure and temperature.
\end{abstract}

We used these new data to interpret the high electrical conductivity recently observed in the mantle under the Brazilian craton. The anomalously elevated conductivity most likely images the process of lithospheric rejuvenation involving 0.03 to $0.2 \%$ of carbonated melt.

\section{Keywords}

- Carbonated melt;

- Electrical conductivity;

- Viscosity;

- $\mathrm{CO}_{2}$;

- Mantle geophysics;

- Piston cylinder

\section{Introduction}

Melting in the Earth's mantle due to $\mathrm{CO}_{2}$ has long been proved by geochemical observations (Yaxley et al., 1991, Rudnick et al., 1993, Walter et al., 2008, Collerson et al., 2010 and Simonetti and Neal, 2010), and experimental petrology (Wyllie and Huang, 1975, Falloon and Green, 1990, Presnall and Gudfinnsson, 2005, Dasgupta and Hirschmann, 2006 and Ghosh et al., 2014) on peridotitic and eclogitic rocks (Hammouda, 2003 and Dasgupta et al., 2004). All these studies reported that carbon dioxide can strongly reduce mantle solidus temperature even at the very low concentration levels expected in the mantle. Carbonate melts are therefore expected in most of the $\mathrm{P}-\mathrm{T}$ domains of the upper 
mantle, being merely confined by redox boundaries marking the diamond stability field (Rohrbach and Schmidt, 2011 and Stagno et al., 2013).

Their physical properties are much less known (Jones et al., 2013), in particular their electrical conductivity. Existing data were obtained at low pressure (Gaillard et al., 2008 and Kojima et al., 2008) on alkali-rich carbonate melts or at high pressure (Sifré et al., 2014) and on alkali-free carbonate melts with poorly defined temperature and pressure dependence (Yoshino et al., 2010 and Yoshino et al., 2012). Gaillard et al. (2008) showed that carbonated melts are five orders of magnitude more conductive than mantle olivine, and up to three orders of magnitude more conductive than basalt at atmospheric pressure. This observation was corroborated by Sifré et al. (2014) at $3 \mathrm{GPa}$. However, in the absence of systematic data on the effect of chemical composition, pressure and temperature on the conductivity of carbonated melts, it is difficult to quantitatively interpret mantle electrical properties.

In this study, we report measurements of electrical conductivities of dry and hydrous carbonated melts at $\mathrm{HT}\left(>1000{ }^{\circ} \mathrm{C}\right)$ and $\mathrm{HP}(1$ to $4 \mathrm{GPa})$ in a piston cylinder. We describe the effect of chemical composition, temperature and pressure on the electrical conductivity. We propose a calculation to predict the effect of $\mathrm{T}$ and $\mathrm{P}$ by using the Arrhenius parameters determined in this study. These new data provide a link between electrical conductivity and viscosity of carbonatic melts, with a remarkably simple equation. Finally, laboratory-based values and geophysical measurements are confronted allowing quantitative estimations of melt fraction below the Brazilian craton.

\section{Material and methods}

\subsection{Starting material}

Electrical conductivity measurements were performed on six different mixtures (Table 1 and Table 2): 5 dry carbonated melts $\left(\mathrm{CO}_{2}\right.$ ranging from 38 to $\left.49 \mathrm{wt} . \%\right)$ and a hydrous carbonated melt $\left(\mathrm{CO}_{2}=28 \mathrm{wt} . \% ; \mathrm{H}_{2} \mathrm{O}=8 \mathrm{wt} . \%\right)$, the latter corresponding to fluid inclusion compositions found in diamonds (Klein-Bendavid et al., 2009). To obtain these mixtures, starting materials were natural calcite $\left(\mathrm{CaCO}_{3}\right)$, natural dolomite $\left(\mathrm{MgCa}\left(\mathrm{CO}_{3}\right)_{2}\right)$, natural magnesite $\left(\mathrm{MgCO}_{3}\right)$, potassium carbonate $\left(\mathrm{K}_{2} \mathrm{CO}_{3}\right)$, sodium carbonate $\left(\mathrm{Na}_{2} \mathrm{CO}_{3}\right)$, silicon dioxide (amorphous $\mathrm{SiO}_{2}$ ), halite $(\mathrm{NaCl})$ and brucite $\left(\mathrm{Mg}(\mathrm{OH})_{2}\right)$. The starting materials were stored in an electrical oven at $120{ }^{\circ} \mathrm{C}$ before use. Potassium and sodium carbonates were however previously dried at $250{ }^{\circ} \mathrm{C}$ to ensure that they were fully dehydrated. Samples C and MC were cored from natural rocks (Carrara Marble and natural dolomite, Table 1) whereas the other mixtures were weighed in suitable amounts for the desired compositions (MK, CK, MN and MCKNw samples) and then cold pressed into pellets. For samples $\mathrm{MK}, \mathrm{CK}$ and $\mathrm{MN}$, a one to one molar ratio was respected, that is $\mathrm{MgCO}_{3} / \mathrm{K}_{2} \mathrm{CO}_{3}=1$ for $\mathrm{MK}, \mathrm{CaCO}_{3} / \mathrm{K}_{2} \mathrm{CO}_{3}=1$ for $\mathrm{CK}$ and $\mathrm{MgCO}_{3} / \mathrm{Na}_{2} \mathrm{CO}_{3}=1$ for $\mathrm{MN}$. Concerning composition MCKNw, a molar ratio of $\mathrm{CO}_{2} /\left(\mathrm{CO}_{2}+\mathrm{H}_{2} \mathrm{O}\right)=0.65$ was considered for the volatile content.

\subsection{High-pressure conductivity measurements}

Experiments were performed in $1 / 2$-inch piston cylinders (graphite-Pyrex-talc assemblages) at pressures ranging from 1 to $4 \mathrm{GPa}$. These experiments were connected to a 1260 Solartron Impedance/Gain Phase Analyzer for the electrical conductivity measurements. Temperature 
was measured with a B-type thermocouple localized on top of the sample (Figs. 1 and S1). The oxygen fugacity $\left(\mathrm{fO}_{2}\right)$ was not controlled during the measurements but the presence of the graphite furnace and molten carbonate samples should imply a fO $\mathrm{f}_{2}$ close to FMQ-2 (Stagno et al., 2013).

A protocol used for measurements has been specifically developed for electrical conductivity measurements on highly conductive molten materials (Fig. 1). A pseudo 4-wire configuration was designed, which removed the electrical contribution of the electrical cell itself. A blank test is presented in Fig. 2, the measured resistance consisting of the blank assemblage (i.e. the metal plug (Fig. 1), the Pt foil ( $25 \mu \mathrm{m}$ in thickness and $15 \mathrm{~mm}$ length) and a Ni sample). Fig. 2 shows that the electrical conductivity of the electrical cell itself is two orders of magnitude lower than the carbonated melt, confirming the use of a 4-wire configuration. Such a configuration previously adapted at 1 atm (Gaillard, 2004 and Gaillard et al., 2008) and $3 \mathrm{GPa}$ (Sifré et al., 2014) was judged necessary for our measurements at high pressure.

An inner Pt electrode (1 mm diameter) was placed in the centre of the cold-pressed pellets or the centre of the natural cores ( $5 \mathrm{~mm}$ outer diameter). A Pt foil was positioned around the sample and used as the second outer electrode. The sample (approx. $2 \mathrm{~mm}$ length) was surrounded at the top and at the bottom by two MgO plugs (Fig. 1) that were previously annealed at $1000{ }^{\circ} \mathrm{C} / 1 \mathrm{~atm}$ for $2 \mathrm{~h}$. The length of each $\mathrm{MgO}$ plug was adjusted in order to position the sample at the centre of the furnace. The entire electrical cell was isolated from the graphite furnace by an alumina jacket (Fig. 1). The sample impedance was therefore measured between the two electrodes in a co-axial geometry (Gaillard, 2004 and Hashim et al., 2013). Connection between the inner electrode and the impedance spectrometer was achieved by means of the thermocouple wires (Hashim et al., 2013). The outer electrode was connected to a nickel cylinder (metal plug in Fig. 1), the latter located $5 \mathrm{~mm}$ above the sample, which was mounted in series with two additional wires (B-type thermocouples), as shown in Fig. 1.

Impedance spectra were collected during heating and cooling cycles at different temperature plateaux in the frequency range of $1 \mathrm{~Hz}$ to $1 \mathrm{MHz}$ (data collection < $2 \mathrm{~h}$, Fig. S2). In the case of the hydrated sample (MCKNw), the heating cycle was slightly different: the temperature was rapidly (less than $2 \mathrm{~min}$ ) increased to the maximum temperature (Table 3 ) in order to trap the volatiles (released by the brucite compound) into the molten sample. Electrical conductivity measurements were therefore conducted during the cooling cycle and the second heating cycle (except for the run at $4 \mathrm{GPa}$ where no measurement was made during the second heating cycle; Table 3 ).

For temperatures lower than the melting temperature, $\mathrm{T}_{\mathrm{m}}$, the collected spectra showed impedance arcs, whereas for temperatures $>T_{m}$ the produced spectra exhibited vertical lines. These low- and high-temperature spectra correspond to capacitance-dominated and inductance-dominated signals, where the intercept of each spectrum with the $\mathrm{X}$-axis yielded the resistance of the studied sample.

Validation of each electrical value was achieved by reproducing the measurements during both heating and cooling cycles. Any measurements failing in satisfying this requirement were discarded.

The electrical conductivity of the different samples was calculated from the measured resistance, $R$ (in $\Omega$ ) ( Gaillard, 2004 and Hashim et al., 2013), using: 
$\sigma=\left(\ln \left(\mathrm{r}_{\text {out }} / \mathrm{r}_{\text {in }}\right)\right) /(2 \pi \mathrm{hR})$

with $\sigma$, the calculated electrical conductivity in $\mathrm{S} \cdot \mathrm{m}^{-1} ; r_{\text {out }}$ and $r_{i n}$, the outer and inner radii of the sample (in m) and $h$, the height of the sample (in m). Density measurements (Dobson et al., 1996 and Liu et al., 2011) show that for the temperature ranges considered in this study, melt should expand on average by $3 \%$. Since the sample is placed in a co-axial geometry, thermal expansion is therefore considered negligible and the radii ratio should be kept constant during the experiments.

Uncertainties on $\sigma$ were calculated considering the geometrical factors of the sample (i.e. $r_{\text {out }}$, $r_{i n}$ and $h$; see Section 2.4.) and the propagated errors of each measured resistance. Uncertainties on $\sigma$ are of about $10 \%$ on average for all measurements.

\subsection{Validation of protocol}

In order to validate the previously described protocol, the electrical conductivity measurements of samples $\mathrm{C}$ and $\mathrm{MC}$ obtained during the heating cycle were compared to established phase diagrams of natural calcite and dolomite. Fig. 3 shows an increase in electrical conductivity with increasing temperature and a slope shift for each sample. Sample MC presents a slope rupture between 1300 and $1315^{\circ} \mathrm{C}$ at $3 \mathrm{GPa}$. The slope rupture for sample $\mathrm{Ca}$ is at higher temperatures, i.e. between 1416 and $1423{ }^{\circ} \mathrm{C}$ at $1 \mathrm{GPa}$, and between 1542 and $1558{ }^{\circ} \mathrm{C}$ at $3 \mathrm{GPa}$. These slope shifts indicate a change within the samples, from solid state for low temperatures to molten state at higher temperatures. The electrical conductivity is therefore directly impacted by this state change since the conduction mechanism switches from an electronic conduction mechanism in solids at low temperatures (Mirwald, 1979) to an ionic conduction mechanism in liquids (Gaillard et al., 2008 and Kojima et al., 2008). Previously, phase diagrams indicate that $\mathrm{CaCO}_{3}$ melt at such temperatures at 1 and $3 \mathrm{GPa}\left(1417^{\circ} \mathrm{C}\right.$ and $1558{ }^{\circ} \mathrm{C}$, respectively; Suito et al., 2001). The melting temperature of $\mathrm{MgCa}\left(\mathrm{CO}_{3}\right)_{2}$ at $2.7 \mathrm{GPa}$, approx. $1300{ }^{\circ} \mathrm{C}$, determined in this study is also in agreement with previously published phase diagrams (Wyllie and Lee, 1998). Melting temperatures determined from the in situ electrical conductivity measurements on natural calcite and dolomite are in very good agreement with previously published phase diagrams.

Electrical conductivity measurements were also conducted on solid calcite at a pressure of 2.5 GPa (Bagdassarov and Slutskii, 2003) and are in good agreement with the measurements on sample $\mathrm{C}$ from this study for temperatures $<1558^{\circ} \mathrm{C}$ at $3 \mathrm{GPa}$ (Fig. S3). The electrical conductivity measurements performed here are therefore consistent with previous studies on $\mathrm{CaCO}_{3}$ and $\mathrm{MgCa}\left(\mathrm{CO}_{3}\right)_{2}$, thus validating our newly defined protocol.

\subsection{Analytical techniques and imaging}

After each experiment, the samples were mounted in epoxy and cut along the longitudinal axial section. A scanning electron microscope (SEM) was used on the polished mounts, that were previously carbon-coated, at back-scattered electron mode to image the sample geometry. A decrease of about $20 \%$ for parameters $r_{\text {out }}, r_{\text {in }}$ and $h$ compared to the initial geometry was observed on the SEM images, which is most likely due to porosity loss during melting ( Fig. S1). The SEM images also showed that the samples remained sandwiched between the $\mathrm{MgO}$ plugs and electrodes. A 3D reconstruction of one of the samples by 
microtomography showed that the sample remained cylindrical after the experiment and indicated the same diameter than on SEM images.

Chemical compositions and homogeneity of the melt phase were obtained using an electron microprobe (EMP). EMP analyses were conducted at $15 \mathrm{kV}, 10 \mathrm{nA}$ and $10 \mathrm{~s}$ counting on peak elements. In order to smooth heterogeneities due to quench crystallizations, the beam size $(100 \mu \mathrm{m} \times 100 \mu \mathrm{m})$ was adapted to obtain average chemical compositions.

Table 1 and Table 2 indicate that there was no contamination by the $\mathrm{MgO}$ plugs surrounding the sample (except a minor increase for sample $\mathrm{C}$, that has been exposed to very high $\mathrm{T}$, whereas most of our measurements were conducted at $\mathrm{T}<1500{ }^{\circ} \mathrm{C}$ ) and no considerable volatile loss from the sample after the experiments. The carbonate $\left(\mathrm{CO}_{2}\right)$ concentration in the melt was calculated from the total weight deficit of the EMP analyses (Dasgupta et al., 2007) and indicates negligible decarbonation. Sample $\mathrm{C}$ was also analysed by X-ray diffraction before and after the experimental run (Fig. S4) confirming that no decarbonation happened.

For sample MCKNw, an elemental analyzer, type Flash 2000 (Thermo Scientific), was used to measure the $\mathrm{H}_{2} \mathrm{O}$ content of the sample before and after the experiments. During these analyses, $\mathrm{H}_{2} \mathrm{O}$ was released from the samples as reduced elemental $\mathrm{H}$ during the heating step (up to $>1500{ }^{\circ} \mathrm{C}$ ), which was detected by a highly sensitive thermal conductivity detector. This method thus provides the water content of the samples with a precision of $\pm 0.5 \mathrm{wt} . \%$. During the electrical conductivity measurements, dehydration was therefore considered negligible, as noticed by Laumonier et al. (in press) on dacite up to $12 \mathrm{wt}$. $\%$ of $\mathrm{H}_{2} \mathrm{O}$.

\section{Results}

\subsection{Chemical and temperature effects}

The electrical conductivity of the molten state samples at constant pressure ( $3 \mathrm{GPa}$ ) is given in Fig. 4 in a $\log \sigma$ vs. $10^{4} / \mathrm{T}$ plot (the complete data set from solid state to molten state is shown in Fig. S3). The collected data for each experiment shows good reproducibility during both the heating and cooling cycles. Every sample displays the same behaviour; basically the electrical conductivity is poorly dependent on temperature since it increases linearly by only a factor of 2 with increasing temperature within the T-range investigated here. As an example, the electrical conductivity of sample $\mathrm{CK}$ has a value of $60 \mathrm{~S} \cdot \mathrm{m}^{-1}$ at $1090{ }^{\circ} \mathrm{C}$ and increases to a value of $120 \mathrm{~S} \cdot \mathrm{m}^{-1}$ at $1433^{\circ} \mathrm{C}$ (Fig. 4).

Electrical conductivity values for the samples studied at $3 \mathrm{GPa}$ range between $54 \mathrm{~S} / \mathrm{m}$ for sample $\mathrm{CK}$ at $1000{ }^{\circ} \mathrm{C}$ and $260 \mathrm{~S} / \mathrm{m}$ for sample $\mathrm{C}$ at $1677^{\circ} \mathrm{C}$. These electrical values show that carbonated melts are five orders of magnitude more conductive than mantle olivine (Wang et al., 2006 and Yoshino et al., 2006), and up to two orders of magnitude more conductive than basalt (Tyburczy and Waff, 1983 and Ni et al., 2011) at mantle conditions. Fig. 4 shows that there is essentially a poor chemical composition effect on the electrical conductivity for the compositions studied here.

Since the electrical conductivity behaves linearly with the reciprocal temperature, each sample can be fitted using the following Arrhenius expression:

$\sigma=\sigma_{0} \cdot \exp \left(-\mathrm{E}_{\mathrm{a}} / \mathrm{RT}\right)$ 
where $\sigma_{0}$ is the pre-exponential factor (in $\mathrm{S} / \mathrm{m}$ ), $E_{a}$ is the activation energy (in $\mathrm{J} / \mathrm{mol}$ ), $R$ is the gas constant and $\mathrm{T}$ is the temperature (in $\mathrm{K}$ ). For a better fit of the above parameters, the hightemperature dataset of sample $\mathrm{C}\left(1570{ }^{\circ} \mathrm{C}<\mathrm{T}<1677{ }^{\circ} \mathrm{C}\right.$, small circles in Fig. 4) was neglected because of a low temperature precision due to the B-type thermocouple. Fitted parameters are listed in Table 3. Fitted $E_{a}$ valuesare essentially similar for all compositions, ranging from 37 to $47 \mathrm{~kJ} / \mathrm{mol}$.

\subsection{Pressure effect}

Electrical conductivity measurements were also performed at different pressures in order to assess the effect of pressure on the conductivity. Three different compositions $(\mathrm{C}, \mathrm{CK}$ and $\mathrm{MCNKw}$ ) were studied for pressures ranging from 1 to $4 \mathrm{GPa}$ and are shown in Fig. 5 (the complete data set is shown in Fig. S5). Essentially, the electrical conductivity decreases with increasing pressure. This pressure effect seems however lowered with increasing temperature as seen with sample $\mathrm{C}$ in Fig. 5.

The activation energy decreases with increasing pressure as shown in Fig. 6a. A common activation volume $(\Delta V)$ was calculated by linear regression of the data in an $E_{a}$ vs. pressure plot ( Fig. 6a), yielding a value of $0.275 \pm 0.05 \mathrm{~J} / \mathrm{bar}$, with the following equation:

$\mathrm{Ea}=\Delta \mathrm{H}+\mathrm{P} \cdot \Delta \mathrm{V}$

with $\Delta H$, the activation enthalpy $\left(\mathrm{J} \cdot \mathrm{mol}^{-1}\right.$ ) and $\mathrm{P}$, the pressure (in bar).

Fig. $6 \mathrm{~b}$ shows that the limited experimental data from this study does not indicate any clear pressure effect on the pre-exponential factor, $\sigma_{0}$.

Notwithstanding, the linear fit based on Eqs. (2) and (3) reproduces remarkably well the electrical conductivity values collected in this study (Fig. S5). By using these equations, it is therefore possible to determine the electrical conductivity of molten carbonates at higher or lower pressures than in this study within reasonable error.

\section{Discussion}

\subsection{Chemistry and water effects}

The results of this study globally show a poor chemical effect on the electrical conductivity of molten carbonates. In detail, a correlation between electrical conductivity and the size/charge ratio of the different ions introduced into the melt was observed. Indeed, introduction of small cations, with small charges increases the bulk electrical conductivity of the melt, as shown by the addition of a sodium component in the melt in Fig. 4. This is consistent with the observation of Kojima et al. (2008) and Gaillard et al. (2008) based on 1 atm measurements, where they demonstrated that molten carbonates are increasingly conductive as alkali substitution follows the order $\mathrm{Li}>\mathrm{Na}>\mathrm{K}$.

Replacement of alkalis by alkali-earth elements triggers a decrease in electrical conductivity, as observed in the measurements on Mg-bearing samples, and noticed in earlier studies (Gaillard et al., 2008 and Kojima et al., 2008) on Mg-free Ca-bearing samples. 
Fig. 7 shows a comparison of the electrical conductivity of samples MC and MCKNw with a previous experimental study on molten carbonates (Sifré et al., 2014). For dry carbonated melts, the addition of $10 \mathrm{wt} . \% \mathrm{Na}_{2} \mathrm{CO}_{3}$ or $10 \mathrm{wt} . \% \mathrm{NaCl}$ to a dolomitic composition showed an increase of the electrical conductivity on average by $10 \%$. Adding $\mathrm{Na}_{2} \mathrm{CO}_{3}$ or $\mathrm{NaCl}$ into the melt also decreases the activation energy of the melt (Table 3). Two different hydrated carbonated compositions with essentially the same $\mathrm{CO}_{2} /\left(\mathrm{H}_{2} \mathrm{O}+\mathrm{CO}_{2}\right)$ molar ratio are also compared in Fig. 7. A weak increase of electrical conductivity is observed when $\mathrm{CO}_{2}$ is replaced by $\mathrm{H}_{2} \mathrm{O}$ with respect to a molar ratio of $\mathrm{CO}_{2} /\left(\mathrm{H}_{2} \mathrm{O}+\mathrm{CO}_{2}\right)=0.65$. In silicate melts, water increases the mobility of $\mathrm{Na}^{+}$, being the main charge carrier, which results in an increase of its electrical conductivity (Gaillard, 2004, Pommier et al., 2008 and Ni et al., 2011). In ionic liquids, this water effect is negligible since there is no polymerised structure in the melt inhibiting the diffusion of all cations.

The different melt compositions from this study are compared to previous numerical and experimental studies (Yoshino et al., 2010, Yoshino et al., 2012 and Vuilleumier et al., 2014) on molten carbonated melts in Fig. 8. There is a good agreement between molecular dynamics (MD) simulation on calcitic melts (Vuilleumier et al., 2014) and the electrical conductivity measurement from this study on sample $\mathrm{C}$ at $3 \mathrm{GPa}$. In contrast, the activation energies from both studies at $3 \mathrm{GPa}$ are different, which is also apparent at $1 \mathrm{GPa}$ on the activation energy and the electrical conductivity values. However, it is worth noting that the conductivity values are similar at $1 \mathrm{GPa}$ between the study by Vuilleumier et al. (2014) and this study. Yoshino et al. (2010) measured the electrical conductivity of a molten calcitic melt containing $10 \mathrm{wt} . \%$ $\mathrm{SiO}_{2}$ at $1427^{\circ} \mathrm{C}$. This study yielded a conductivity value slightly lower than the extrapolated electrical conductivity determined here ( $89 \mathrm{~S} / \mathrm{m}$ vs. $120 \mathrm{~S} / \mathrm{m}$, respectively), probably due to the presence of 10\% silica in Yoshino et al (2010)'s experiments. Indeed, Sifré et al. (2014) showed that addition of silicate into a carbonated melt moderately decreases its electrical conductivity for such small amounts of silica added. Yoshino et al. (2012) measured the electrical conductivity of molten dolomite, which is about a factor 2 lower than the values measured on sample MC in this study. Although the melting temperatures in both studies are the same for an equivalent pressure, we are not able to explain the discrepancy in the electrical conductivity values. As a consequence, the studies of Yoshino et al., 2010 and Yoshino et al., 2012 do not show any chemical effect on the electrical conductivity of carbonate melts. The molten calcitic melt containing $10 \mathrm{wt} . \% \mathrm{SiO}_{2}$ and the molten dolomite incidentally show the same electrical conductivity at $1427^{\circ} \mathrm{C}\left(89 \mathrm{~S} \cdot \mathrm{m}^{-1}\right)$. We also note that there is no indication in the electrical measurements of a transition from a molten state to a solid state when decreasing the temperature (Yoshino et al. (2012)). Nonetheless, the electrical conductivity values from the study of Yoshino et al. (2012) are of the same order of magnitude than the values collected in this study.

\subsection{Pressure effect}

Similarly to the chemical effect, the pressure moderately affects the electrical conductivity, as shown in Fig. 5 and Fig. 8 and by the activation volume, $\Delta V$, determined in this study. This negative pressure effect on electrical conductivity is consistent with MD simulations performed by Vuilleumier et al. (2014). The activation volume deduced from the latter study is in excellent agreement with the $\Delta V$ determined here. However, unlike Vuilleumier et al. (2014), the current experimental dataset is insufficient to determine a pressure effect on $\Delta V$. 
Additionally, a previous study on MD simulations performed by Genge et al. (1995) showed that diffusion coefficient of ionic species in molten $\mathrm{CaCO}_{3}$ moderately decreases with increasing pressure from 0.1 to $10 \mathrm{GPa}$. This is consistent with the decrease of $\sigma$ with increasing P, as observed in this study. In silicate melts, it has also been shown that pressure tends to decrease electrical conductivity as reported in Tyburczy and Waff (1983), Gaillard (2004), Pommier et al. (2008).

\subsection{Electrical conductivity and viscosity relationship}

Electrical conductivity and diffusion are two physical parameters that are related by the Nernst-Einstein equation, as follows:

$\mathrm{D}=\left(\sigma \cdot \mathrm{k}_{\mathrm{B}} \cdot \mathrm{T}\right) /\left(\mathrm{q}^{2} \cdot \mathrm{N}\right)$

with $D$, the diffusion coefficient (in $\mathrm{m}^{2} \cdot \mathrm{s}^{-1}$ ), $k_{B}$, the Boltzmann constant, $\mathrm{T}$, the temperature (in $\mathrm{K}$ ), $q$, the charge and $N$, its concentration. Furthermore, viscosity can be related to diffusion by the Eyring equation ( Reid et al., 2001):

$\mathrm{D}=\left(\mathrm{k}_{\mathrm{B}} \cdot \mathrm{T}\right) /(\eta \cdot \lambda)$

where $\eta$ is the viscosity (in $\mathrm{Pa} \cdot \mathrm{s}$ ), and $\lambda$ is the translation distance of the diffusing ion $(\AA)$.

With Eqs. (4) and (5), a relationship between electrical conductivity and viscosity can be deduced:

$\left.H(T)=\left(q^{2} \cdot N\right) / \sigma(T) \cdot \lambda\right)$

The combination of Eqs. (4) and (5) assumes that the same diffusion process controls electrical conductivity and viscosity. For natural silicate melts, it has been shown that $\mathrm{Na}^{+}$is the main charge carrier contributing to their electrical conductivity. The particular diffusive behaviour of alkalis in silicate melts (Jambon, 1982, Henderson et al., 1985, Watson, 1994 and Gaillard and Iacono Marziano, 2005) is uncorrelated to the relaxation time of the Si-O bounds (Pfeiffer, 1998 and Mungall, 2002), which, in turn controls the viscosity. It is therefore clear that Eq. (6) is not valid for natural silicate melts. In alkali-free silicate melts, Eq. (6) has been relatively successfully tested by Gruener et al. (2001) indicating that viscosity, Al-O bounds relaxation times and electrical conductivity can be related. We tested Eq. (6) for carbonate melts: we have therefore used published data on the viscosity of carbonated melts at different pressures and temperatures (Dobson et al., 1996, Kono et al., 2013 and Vuilleumier et al., 2014) and plotted them as a function of the electrical resistivity ( $\rho$, i.e. inverse of electrical conductivity) in Fig. 9. The electrical resistivity for each composition was recalculated with the Arrhenius parameters, as determined in Table 3, at the pressure and temperature conditions at which viscosity values were obtained by Dobson et al. (1996), Kono et al. (2013), and Vuilleumier et al. (2014). Fig. 9 shows that the electrical conductivity values calculated with the parameters in Table 3 are in good agreement with the electrical conductivity deduced by MD simulation (Vuilleumier et al., 2014; open circles vs. half empty circles in Fig. 9). In the first approximation, there is a remarkably simple correlation for carbonated melts between viscosity and electrical conductivity, such as:

$\eta=1 / \sigma( \pm 10 \%)$. 
The diffusive process rate-limiting electrical conductivity and viscosity must be similar in molten carbonates. It is certainly related to the ionic nature of such liquids (like molten salts see Jones et al, 2013 and ref therein) implying the combined and coordinated motion of all charged ions (at the same rates). The use of the Nernst-Einstein (Eq. (4)) indicates an average diffusion rate of $10^{-9}$ to $10^{-8} \mathrm{~m} \cdot \mathrm{s}^{-1}$ for all the melt compositions investigated in this study. Similar diffusion rates were also obtained on alkali-rich melts (Gaillard et al., 2008). A diffusion rate of ca. $10^{-9} \mathrm{~m} \cdot \mathrm{s}^{-2}$ is also deduced by MD simulations for all ionic species in molten calcite (Genge et al., 1995).

A brief application of the electrical conductivity/viscosity correlation defined in Eq. (7) can be made on the peridotitic or eclogitic mantle. Most diamond inclusions, which are probably residual carbonated melts (e.g. sample $\mathrm{MCKNw}$ ), indicate growth conditions at temperatures of 900-1300 ${ }^{\circ} \mathrm{C}$ and at a depth range of 150 to $200 \mathrm{~km}$ (Meyer and McCallum, 1986, Harris, 1993 and Stachel and Harris, 2008). By using Eq. (3), such hydrated carbonated melts should imply electrical conductivities ranging between 20 and $115 \mathrm{~S} \cdot \mathrm{m}^{-1}$ and as a result, viscosities between 0.008 and $0.05 \mathrm{~Pa} \cdot \mathrm{s}$.

\subsection{Geophysical application}

Recent electromagnetic surveys (Bologna et al., 2005 and Pinto et al., 2010) revealed highly conductive intrusions in the lithosphere beneath the Brazilian craton: -2 to $-1.25 \mathrm{~S} \cdot \mathrm{m}^{-1}$ at 120-140 km depth. Carbonatite melts have been suggested to rise in the resistive cratonic lithosphere generating rejuvenation and re-oxidation of the reduced mantle (Pinto et al., 2010).

By using the carbonatite melts hypothesis and well-known electrical mixing laws, such as the tube model (Grant and West, 1965 and Schmeling, 1986), we can estimate the amount of melts needed to infer such high conductivity values beneath the Brazilian craton. For the calculations, we consider a reference geotherm at 4 GPa from Pollack and Chapman (1977), the electrical conductivity of the solid framework assessed by Jones et al. (2012) as well as the electrical conductivity of sample MCKNw, which represent the closest melt composition to the mantle from this study (Klein-Bendavid et al., 2009). Small amounts of carbonated melts $(0.03$ to $0.2 \%)$ are therefore needed to explain the electrical anomalies beneath the Brazilian craton detected by geophysical surveys (Fig. 10a).

As suggested in Pinto et al. (2010), electromagnetic surveys are expected to image large scale geological processes such as lithospheric rejuvenation, metasomatic oxidation and their relationships with diamond destruction/formation (Fig. 10b; Klein-BenDavid et al., 2007, Creighton et al., 2009, Foley, 2008 and Shirey et al., 2013).

\section{Conclusion}

A new dataset of electrical conductivity measurements performed on molten carbonates at high temperature and high pressure reveals poor temperature, pressure and chemical effects. Since the electrical conductivity of carbonated melts follows an Arrhenius law, the Arrhenius parameters were determined and the electrical conductivity of these melts can therefore be extrapolated to higher and lower temperatures and pressures. This study also established a correlation between electrical conductivity and viscosity of carbonated melts, making it possible to predict the viscosity in the underlying mantle of these ionic liquids. 
The electrical conductivity/viscosity relationship established here is however simple and requires further study with a wider range of temperatures and pressure as well as a more complex range of chemical composition of molten carbonates and carbonated basalts. These future studies will subsequently help us in establishing a more robust correlation between these two physical properties.

\section{Acknowledgements}

This work, part of the ElectroLith project, benefited from funding by the European Research Council (ERC project \#279790) and the French agency for research (ANR project \#2010 BLAN62101). The authors would like to thank Klaus Mezger and Carmen Sanchez-Valle for careful and efficient editorial handling as well as two anonymous reviewers for their constructive comments that significantly improved the manuscript. We also acknowledge Ida Di Carlo for analytical support, Marielle Hatton for elemental analyses and Esteban Le Moing and Rémy Planckaert for technical assistance.

\section{References}

Bagdassarov and Slutskii, 2003

N.S. Bagdassarov, A.B. Slutskii

Phase transformations in calcite from electrical impedance measurements

Phase Transit., 16 (2003), pp. 1015-1028

Bologna et al., 2005

M.S. Bologna, A.L. Padilha, I. Vitorello

Geoelectric crustal structures off the SW border of the Sao Francisco craton, central Brazil, as inferred from a magnetotelluric survey

Geophys. J. Int., 162 (2005), pp. 357-370

Collerson et al., 2010

K.D. Collerson, Q. Williams, A.E. Ewart, D.T. Murphy

Origin of HIMU and EM-1 domains sampled by ocean island basalts, kimberlites and carbonatites: the role of $\mathrm{CO}_{2}$-fluxed lower mantle melting in thermochemical upwellings Phys. Earth Planet. Inter., 181 (2010), pp. 112-131

Creighton et al., 2009

S. Creighton, T. Stachel, S. Matveev, H. Höfer, C. McCammon, R.W. Luth

Oxidation of the Kaapvaal lithospheric mantle driven by metasomatism

Contrib. Mineral. Petrol., 157 (2009), pp. 491-504

Dasgupta and Hirschmann, 2006

R. Dasgupta, M.M. Hirschmann

Melting in the Earth's deep upper mantle caused by carbon dioxide

Nature, 440 (2006), pp. 659-662

Dasgupta et al., 2004

R. Dasgupta, M.M. Hirschmann, A.C. Withers

Deep global cycling of carbon constrained by the solidus of anhydrous, carbonated eclogite under upper mantle conditions

Earth Planet. Sci. Lett., 227 (2004), pp. 73-85 
Dasgupta et al., 2007

R. Dasgupta, M.M. Hirschmann, N.D. Smith

Partial melting experiments of peridotite $+\mathrm{CO}_{2}$ at $3 \mathrm{GPa}$ and genesis of alkalic ocean island basalts

J. Petrol., 48 (2007), pp. 2093-2124

Dobson et al., 1996

D.P. Dobson, et al.

In-situ measurement of viscosity and density of carbonate melts at high pressure

Earth Planet. Sci. Lett., 143 (1996), pp. 207-215

Falloon and Green, 1990

T.J. Falloon, D.H. Green

Solidus of carbonated fertile peridotite under fluid-saturated conditions

Geology, 18 (1990), pp. 195-199

Foley, 2008

S.F. Foley

Rejuvenation and erosion of the cratonic lithosphere

Nat. Geosci., 1 (2008), pp. 503-510

Gaillard, 2004

F. Gaillard

Laboratory measurements of electrical conductivity of hydrous and dry silicic melts under pressure

Earth Planet. Sci. Lett., 218 (2004), pp. 215-228

Gaillard and Iacono Marziano, 2005

F. Gaillard, G. Iacono Marziano

Electrical conductivity of magma in the course of crystallization controlled by their residual liquid composition

J. Geophys. Res., 110 (2005), pp. 1-12

Gaillard et al., 2008

F. Gaillard, M. Malki, G. Iacono-Marziano, M. Pichavant, B. Scaillet

Carbonatite melts and electrical conductivity in the asthenosphere

Science, 322 (2008), pp. 1363-1365

Genge et al., 1995

M.J. Genge, G.D. Price, A.P. Jones

Molecular dynamics simulations of $\mathrm{CaCO}_{3}$, melts to mantle pressures and temperatures:

implications for carbonatite magmas

Earth Planet. Sci. Lett., 131 (1995), pp. 225-238

Ghosh et al., 2014

S. Ghosh, K. Litasov, E. Ohtani

Phase relations and melting of carbonated peridotite between 10 and $20 \mathrm{GPa}$ : a proxy for alkali- and $\mathrm{CO}_{2}$-rich silicate melts in the deep mantle

Contrib. Mineral. Petrol., 167 (2014), p. 964 
Grant and West, 1965

F.S. Grant, G.F. West

Introduction to the electrical methods

R.R. Shrock (Ed.), Interpretation Theory in Applied Geophysics, McGraw-Hill, New York (1965), pp. 385-401

Gruener et al., 2001

G. Gruener, P. Odier, D. De Sousa Meneses, P. Florian, P. Richet

Bulk and local dynamics in glass-forming liquids: a viscosity, electrical conductivity, and NMR study of aluminosilicate melts

Phys. Rev. B, 64 (2001), p. 024206

Hammouda, 2003

T. Hammouda

High-pressure melting of carbonated eclogite and experimental constraints on carbon recycling and storage in the mantle

Earth Planet. Sci. Lett., 214 (2003), pp. 357-368

Harris, 1993

J.W. Harris

The geology od diamond - Time and depth profiles from inclusions

Diam. Relat. Mater., 2 (1993), pp. 75-79

Hashim et al., 2013

L. Hashim, F. Gaillard, R. Champallier, N. Le Breton, L. Arbaret, B. Scaillet

Experimental assessment of the relationships between electrical resistivity, crustal melting and strain localization beneath the Himalayan-Tibetan belt

Earth Planet. Sci. Lett., 373 (2013), pp. 20-30

Henderson et al., 1985

P. Henderson, J. Nolan, G.C. Cunningham, R.K. Lowry

Structural controls and mechanisms of diffusion in natural silicate melts

Contrib. Mineral. Petrol., 89 (1985), pp. 263-272

Jambon, 1982

A. Jambon

Tracer diffusion in granitic melts: experimental results for $\mathrm{Na}, \mathrm{K}, \mathrm{Rb}, \mathrm{Cs}, \mathrm{Ca}, \mathrm{Sr}, \mathrm{Ba}, \mathrm{Ce}, \mathrm{Eu}$ to $1300{ }^{\circ} \mathrm{C}$ and a model of calculation

J. Geophys. Res., 87 (1982), pp. 797-810

Jones et al., 2012

A.G. Jones, J. Fullea, R.L. Evans, M.R. Muller

Water in cratonic lithosphere: calibrating laboratory determined models of electrical conductivity of mantle minerals using geophysical and petrological observations

Geochem. Geophys. Geosyst., 13 (2012)

Jones et al., 2013

A.P. Jones, M. Genge, L. Carmody

Carbonate melts and carbonatites 
Rev. Mineral., 75 (2013), pp. 289-322

Klein-BenDavid et al., 2007

O. Klein-BenDavid, E.S. Izraeli, E. Hauri, O. Navon

Fluid inclusions in diamonds from the Diavik mine, Canada and the evolution of diamondforming fluids

Geochim. Cosmochim. Acta, 71 (2007), pp. 723-744

Klein-Bendavid et al., 2009

O. Klein-Bendavid, A.M. Logvinova, M. Schrauder, Z.V. Spetius, Y. Weiss, E.H. Hauri, F.V. Kaminsky, N.V. Sobolev, O. Navon

High-Mg carbonatitic microinclusions in some Yakutian diamonds - a new type of diamondforming fluid

Lithos, 112 (2009), pp. 648-659

Kojima et al., 2008

T. Kojima, Y. Miyazaki, K. Nomura, K. Tanimoto

Density, surface tension, and electrical conductivity of ternary molten carbonate system

$\mathrm{Li}_{2} \mathrm{CO}_{3}-\mathrm{Na}_{2} \mathrm{CO}_{3}-\mathrm{K}_{2} \mathrm{CO}_{3}$ and methods for their estimation

J. Electrochem. Soc., 155 (2008), pp. 150-156

Kono et al., 2013

Y. Kono, C. Kenney-Benson, H. Ohfuji, C. Park, G. Shen, Y. Wang

Low viscosity of carbonate melts determined by falling sphere viscometry using ultrafast $\mathrm{X}$ ray imaging at high pressures up to $6 \mathrm{GPa}$

AGU2013 (2013)

Laumonier et al., in press

M. Laumonier, F. Gaillard, D. Sifré

The Effect of Pressure and Water Concentration on the Electrical Conductivity of Dacitic Melts: Implication for Magnetotelluric Imaging in Subduction Areas

(2014) doi10.1016/j.chemgeo.2014.09.019 (in press)

Liu et al., 2011

O. Liu, T.J. Izraeli, R.A. Lange

Do carbonate liquids become denser than silicate liquids at pressure? Constraints from the fusion curve of $\mathrm{K}_{2} \mathrm{CO}_{3}$ to $3.2 \mathrm{GPa}$

Contrib. Mineral. Petro., 153 (2007), pp. 55-66

Meyer and McCallum, 1986

H. Meyer, M. McCallum

Mineral inclusions in diamonds from the sloan kimberlites, Colorado

J. Geol., 94 (1986), pp. 600-612

Mirwald, 1979

P.W. Mirwald

The electrical conductivity of calcite between 300 and $1200{ }^{\circ} \mathrm{C}$ at $\mathrm{CO}_{2}$ pressure 40 bars

Phys. Chem. Miner., 4 (1979), pp. 291-297

Mungall, 2002 


\section{J.E. Mungall}

Empirical models relating viscosity and tracer diffusion in magmatic silicate melts

Geochim. Cosmochim. Acta, 66 (2002), pp. 125-143

Ni et al., 2011

H. Ni, H. Keppler, H. Behrens

Electrical conductivity of hydrous basaltic melts: implications for partial melting in the upper mantle

Contrib. Mineral. Petrol., 162 (2011), pp. 637-650

Pfeiffer, 1998

A. Pfeiffer

Viscosities and electrical conductivities of oxidic glass-forming melts

Solid State Ionics, 105 (1998), pp. 277-287

Pinto et al., 2010

L.G.R. Pinto, M. Banik de Pádua, N. Ussami, Í. Vitorello, A.L. Padilha, C. Braitenberg Magnetotelluric deep soundings, gravity and geoid in the south São Francisco craton: geophysical indicators of cratonic lithosphere rejuvenation and crustal underplating Earth Planet. Sci. Lett., 297 (2010), pp. 423-434

Pollack and Chapman, 1977

H.N. Pollack, D.S. Chapman

On the regional variation of the heat flow, geotherms, and lithospheric thickness

Tectonophysics, 38 (1977), pp. 279-296

Pommier et al., 2008

A. Pommier, F. Gaillard, M. Pichavant, B. Scaillet

Laboratory measurements of electrical conductivities of hydrous and dry Mount Vesuvius melts under pressure

J. Geophys. Res. Solid Earth, 113 (2008), p. B05205

Presnall and Gudfinnsson, 2005

D.C. Presnall, G.H. Gudfinnsson

Carbonate-rich melts in the oceanic low velocity zone and deep mantle

,in: G.R. Foulger, J. Natland, D.C. Presnall, D.L. Anderson (Eds.), Plates, Plumes, and

Paradigms. Geol. Society of America, Special Papers, 388 (2005), pp. 207-216

Reid et al., 2001

J.E. Reid, B.T. Poe, D.C. Rubie, N. Zotov, M. Wiedenbeck

The self-diffusion of silicon and oxygen in diopside $\left(\mathrm{CaMgSi}_{2} \mathrm{O}_{6}\right)$ liquid up to $15 \mathrm{GPa}$

Chem. Geol., 174 (2001), pp. 77-86

Rohrbach and Schmidt, 2011

A. Rohrbach, M.W. Schmidt

Redox freezing and melting in the Earth's deep mantle resulting from carbon-iron redox coupling

Nature, 472 (2011), pp. 209-212 
Rudnick et al., 1993

R.L. Rudnick, W.F. McDonough, B.W. Chappell

Carbonatite metasomatism in the northern Tanzanian mantle: petrographic and geochemical characteristics

Earth Planet. Sci. Lett., 114 (1993), pp. 463-475

Schmeling, 1986

H. Schmeling

Numerical models on the influence of partial melt on elastic, anelastic and electric properties of rocks. Part II: electrical conductivity

Phys. Earth Planet. Inter., 43 (1986), pp. 123-136

Shirey et al., 2013

S.B. Shirey, P. Cartigny, D.J. Frost, et al.

Diamonds and the geology of mantle carbon

Rev. Mineral., 75 (2013), pp. 355-421

Sifré et al., 2014

D. Sifré, E. Gardés, M. Massuyeau, L. Hashim, S. Hier-Majumder, F. Gaillard

Electrical conductivity during incipient melting in the oceanic low-velocity zone

Nature, 509 (2014), pp. 81-85

Simonetti and Neal, 2010

A. Simonetti, C.R. Neal

In-situ chemical, $\mathrm{U}-\mathrm{Pb}$ dating, and $\mathrm{Hf}$ isotope investigation of megacrystic zircons, Malaita

(Solomon Islands): evidence for multi-stage alkaline magmatic activity beneath the Ontong

Java Plateau

Earth Planet. Sci. Lett., 295 (2010), pp. 251-261

Stachel and Harris, 2008

T. Stachel, J.W. Harris

The origin of cratonic diamonds - constraints from mineral inclusions

Ore Geol. Rev., 34 (2008), pp. 5-32

Stagno et al., 2013

V. Stagno, D.O. Ojwang, C.A. McCammon, D.J. Frost

The oxidation state of the mantle and the extraction of carbon from Earth's interior

Nature, 493 (2013), p. 84

Suito et al., 2001

K. Suito, J. Namba, T. Horikawa, Y. Taniguchi, N. Sakurai, M. Kobayashi, A. Onodera, O. Shimomura, T. Kikegawa

Phase relations of $\mathrm{CaCO}_{3}$ at high pressure and high temperature

Am. Mineral., 86 (2001), pp. 997-1002

Tyburczy and Waff, 1983

J.A. Tyburczy, H.S. Waff

Electrical conductivity of molten basalt and andesite to 25 kilobars pressure: geophysical significance and implications for charge transport and melt structure

J. Geophys. Res., 88 (1983), pp. 2413-2430 
Vuilleumier et al., 2014

R. Vuilleumier, A. Seitsonen, N. Sator, B. Guillot

Structure, equation of state and transport properties of molten calcium carbonate $\left(\mathrm{CaCO}_{3}\right)$ by atomistic simulations

Geochim. Cosmochim. Acta, 141 (2014), pp. 547-566

Walter et al., 2008

M.J. Walter, G.P. Bulanova, L.S. Armstrong, S. Keshav, J.D. Blundy, G. Gudfinnsson, O.T. Lord, A.R. Lennie, S.M. Clark, C.B. Smith, L. Gobbo

Primary carbonatite melt from deeply subducted oceanic crust

Nature, 454 (2008), p. 622-U30

Wang et al., 2006

D. Wang, M. Mookherjee, Y. Xu, S. Karato

The effect of water on the electrical conductivity of olivine

Nature, 443 (2006), pp. 977-980

Watson, 1994

E.B. Watson

Diffusion in volatile-bearing magmas

,in: M.R. Carroll, J.R. Holloway (Eds.), Volatiles in Magmas, Rev. Mineral., vol. 30, Mineral.

Soc. Am., Washington, D. C. (1994), pp. 371-411

Wyllie and Huang, 1975

P.J. Wyllie, W.L. Huang

Influence of mantle $\mathrm{CO}_{2}$ in generation of carbonatites and kimberlites

Nature, 257 (1975), pp. 297-299

Wyllie and Lee, 1998

P.J. Wyllie, W. Lee

Model system controls on conditions for formation of magnesiocarbonatite and calciocarbonatite magmas from the mantle

J. Petrol., 39 (1998), pp. 1885-1893

Yaxley et al., 1991

G.M. Yaxley, A.J. Crawford, D.H. Green

Evidence for carbonatite metasomatism in spinel peridotite xenoliths from western Victoria,

Australia

Earth Planet. Sci. Lett., 107 (1991), pp. 305-317

Yoshino et al., 2006

T. Yoshino, T. Matsuzaki, S. Yamashita, T. Katsura

Hydrous olivine unable to account for conductivity anomaly at the top of the asthenosphere

Nature, 443 (2006), pp. 973-976

Yoshino et al., 2010

T. Yoshino, M. Laumonier, E. McIsaac, T. Katsura

Electrical conductivity of basaltic and carbonatite melt-bearing peridotites at high pressures: implications for melt distribution and melt fraction in the upper mantle 
Earth Planet. Sci. Lett., 295 (2010), pp. 593-602

Yoshino et al., 2012

T. Yoshino, E. McIsaac, M. Laumonier, T. Katsura

Electrical conductivity of partial molten carbonate peridotite

Phys. Earth Planet. Inter., 194-195 (2012), pp. 1-9 
Table 1.

Chemical composition normalized to $100 \%$ of the volatile-free starting dacite after melting at $1450{ }^{\circ} \mathrm{C}$ and $1 \mathrm{~atm}$.

$\mathrm{SiO}_{2} \mathrm{TiO}_{2} \mathrm{Al}_{2} \mathrm{O}_{3} \mathbf{F e O} \mathrm{MnO} \mathrm{MgO} \mathrm{CaO} \mathrm{Na}_{2} \mathrm{O} \mathrm{K}_{2} \mathrm{O}$

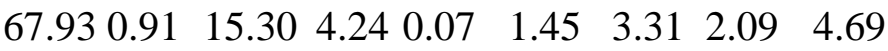

$\begin{array}{llllllllll}1.33 & 0.21 & 0.65 & 0.60 & 0.08 & 0.20 & 0.33 & 0.10 & 0.21\end{array}$
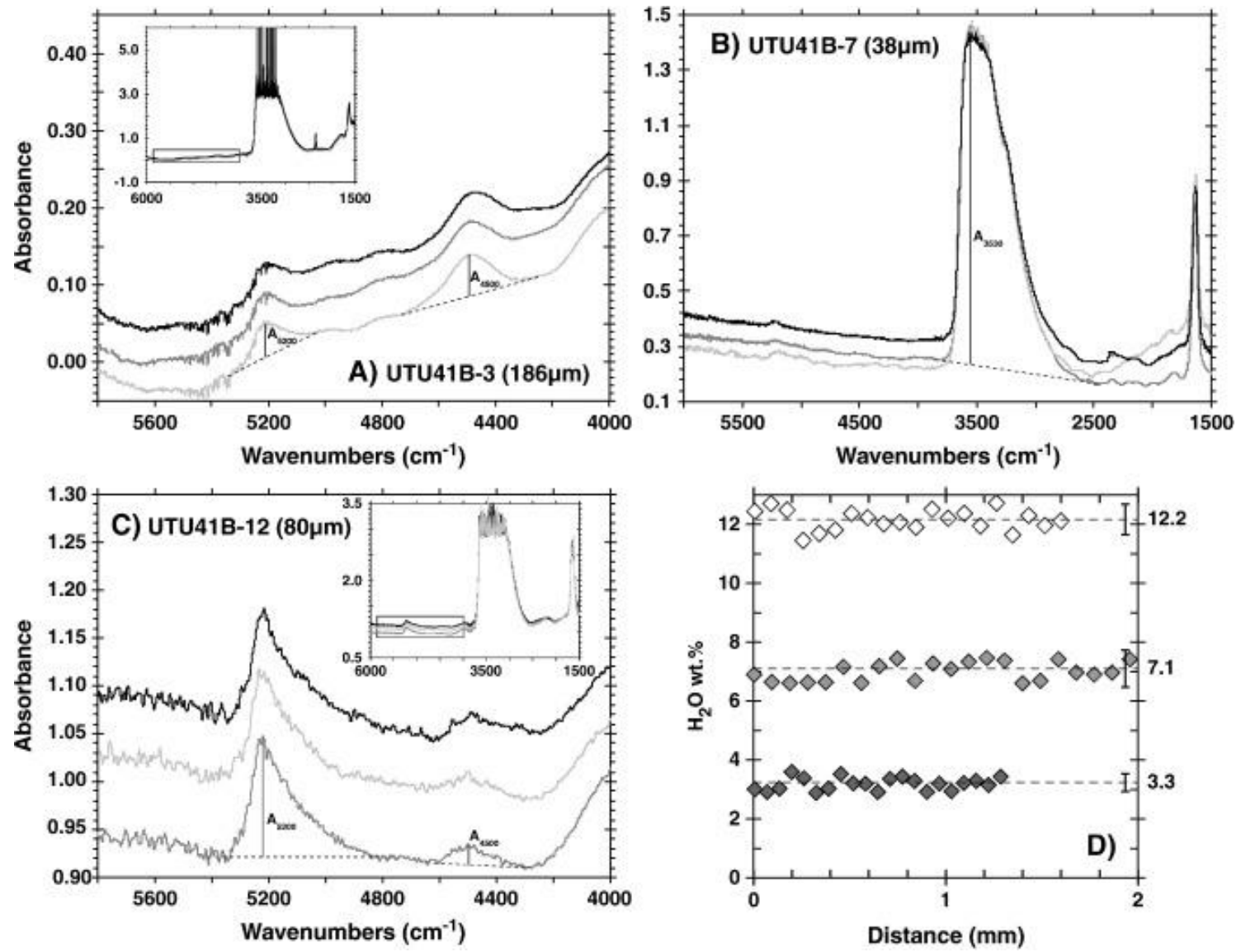

Fig. 1. : Profile of water concentration in the 3 hydrated syntheses obtained by FTIR over 1.3 to $2.0 \mathrm{~mm}$. 


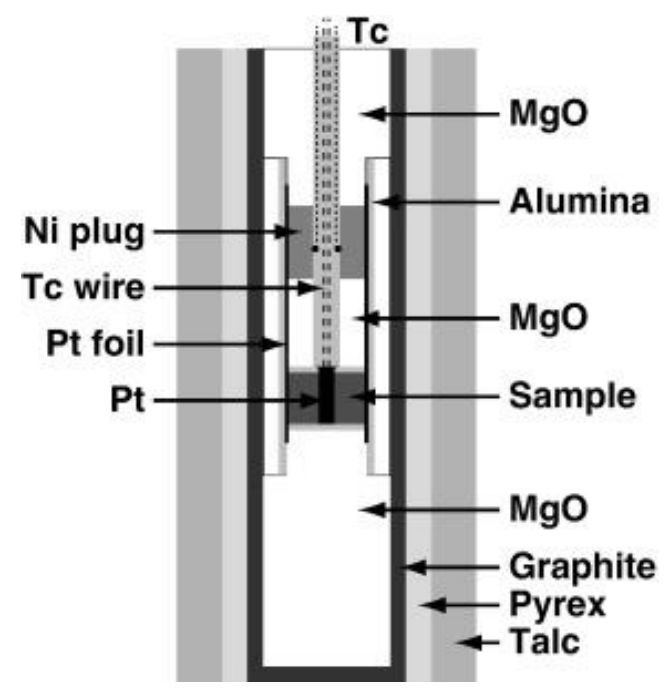

Fig. 2. : 3/4 assembly used for electrical conductivity measurements in piston cylinder.
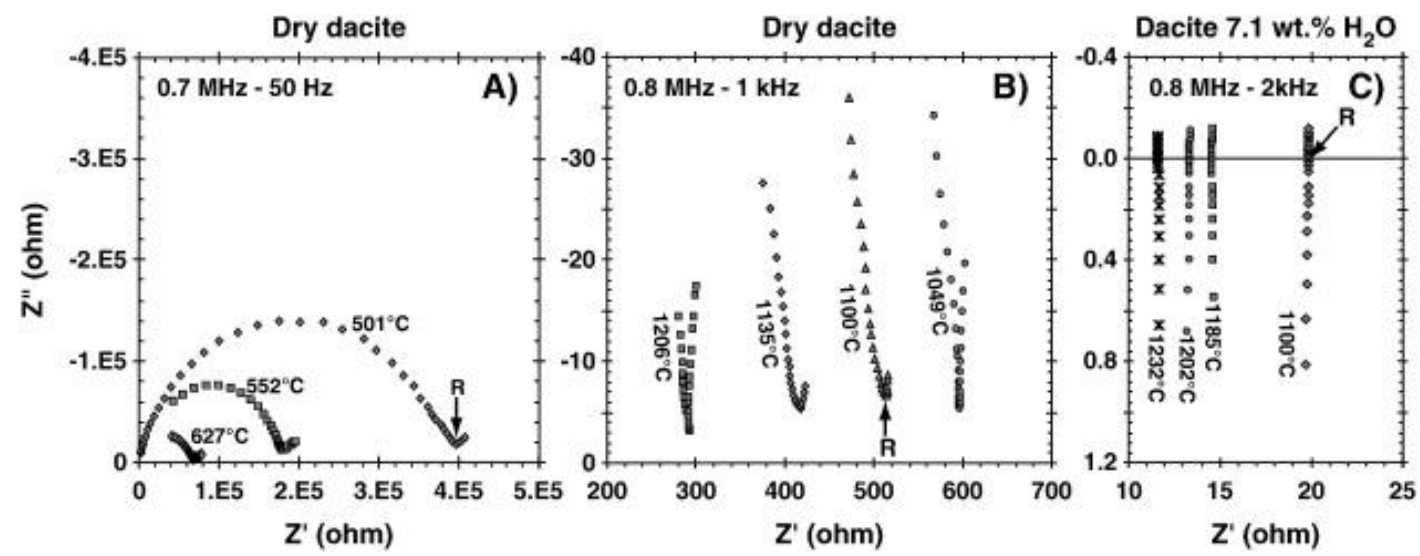

Fig. 3. : Impedance spectra represented in the Nyquist plan $\left(Z^{\prime}, Z^{\prime \prime}\right)$ for the dacite. A) At low temperature and relatively large resistance, the frequency range investigated defines a semicircle corresponding to the electrical response of the sample $\left(R<Z^{\prime}\right)$ and a linear part $\left(\mathrm{R}>\mathrm{Z}^{\prime}\right)$ due to the effect of the interface between the sample and the electrodes. At higher temperatures $(\mathrm{B} \& \mathrm{C}$ ), corresponding to lower resistance values, no impedance arcs were observed; the electrical response is characterized by the decrease and the increase of $Z$ " (B), and by an increase of $Z^{\prime \prime}$ crossing $Z "=0$. The arrow indicates the resistance $R$ of the sample in each type of spectra. 
Table 2.

Experimental details.

\begin{tabular}{|c|c|c|c|c|c|c|c|}
\hline \# exp. & $\begin{array}{l}\text { Starting } \\
\text { material }\end{array}$ & $\begin{array}{c}\mathbf{P} \\
(\mathbf{G P a})\end{array}$ & $\begin{array}{c}\mathbf{T}^{\circ} \mathbf{C} \\
\text { range }\end{array}$ & $\begin{array}{c}\text { Duration } \\
\text { (h) }\end{array}$ & $\begin{array}{c}\text { Water } \\
\text { content } \\
\text { (wt.\%) }\end{array}$ & $\begin{array}{c}\text { Ea } \\
(\mathbf{k J} / \mathbf{m o l})\end{array}$ & $\begin{array}{r}\log \sigma 0 \\
\left(S \cdot m^{-1}\right)\end{array}$ \\
\hline $\begin{array}{l}\text { UTU41B- } \\
0 \mathrm{~g}\end{array}$ & $\begin{array}{l}\text { UTU41B- } \\
\text { dry }\end{array}$ & 0.30 & $\begin{array}{l}400- \\
1214\end{array}$ & 7 & - & 88.3 & 2.6 \\
\hline $\begin{array}{l}\text { UTU41B- } \\
\text { Oe }\end{array}$ & $\begin{array}{l}\text { UTU41B- } \\
\text { dry }\end{array}$ & 0.49 & $\begin{array}{l}400- \\
1211\end{array}$ & 24 & - & 88.2 & 2.5 \\
\hline $\begin{array}{l}\text { UTU41B- } \\
0 \mathrm{i}\end{array}$ & $\begin{array}{l}\text { UTU41B- } \\
\text { dry }\end{array}$ & 2.78 & $\begin{array}{l}400- \\
1350\end{array}$ & 2 & - & 96.4 & 2.7 \\
\hline $\begin{array}{l}\text { UTU41B- } \\
3 \mathrm{~d}\end{array}$ & UTU41B-3 & 0.15 & $\begin{array}{l}500- \\
1107\end{array}$ & 2.5 & 3.25 & 75.8 & 2.8 \\
\hline $\begin{array}{l}\text { UTU41B- } \\
3 \mathrm{c}\end{array}$ & UTU41B-3 & 0.52 & $\begin{array}{l}400- \\
1218\end{array}$ & 3 & 3.28 & 79.1 & 2.8 \\
\hline $\begin{array}{l}\text { UTU41B- } \\
3 \mathrm{f}\end{array}$ & UTU41B-3 & 2.78 & $\begin{array}{l}400- \\
1271\end{array}$ & 2.5 & 3.29 & 89.6 & 3.3 \\
\hline $\begin{array}{l}\text { UTU41B- } \\
7 \mathrm{c}\end{array}$ & UTU41B-7 & 0.56 & $\begin{array}{l}400- \\
1237\end{array}$ & 2.5 & 7.09 & 61.7 & 3.0 \\
\hline $\begin{array}{l}\text { UTU41B- } \\
7 \mathrm{e}\end{array}$ & UTU41B-7 & 2.04 & $\begin{array}{l}400- \\
1211\end{array}$ & 2 & 7.11 & 84.0 & 3.5 \\
\hline $\begin{array}{l}\text { UTU41B- } \\
\text { 7d }\end{array}$ & UTU41B-7 & 3.00 & $\begin{array}{l}400- \\
1204\end{array}$ & 2 & 7.03 & 92.6 & 3.8 \\
\hline $\begin{array}{l}\text { UTU41B- } \\
12\end{array}$ & UTU41B-12 & 3.00 & $\begin{array}{l}400- \\
1219\end{array}$ & 2 & 11.76 & 91.0 & 4.2 \\
\hline
\end{tabular}




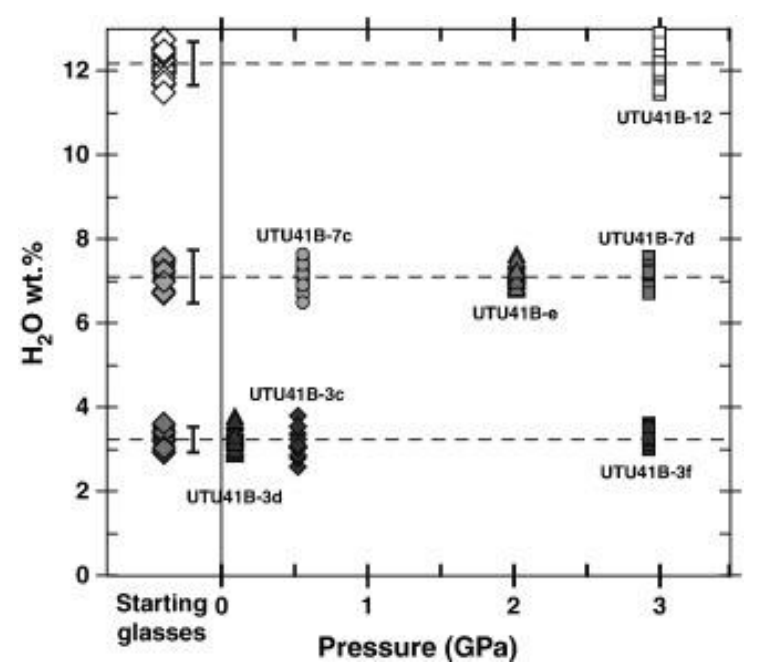

Fig. 4. : Water concentration in the run products according to their pressure, compared with the starting glasses. No significant water loss was noticed.

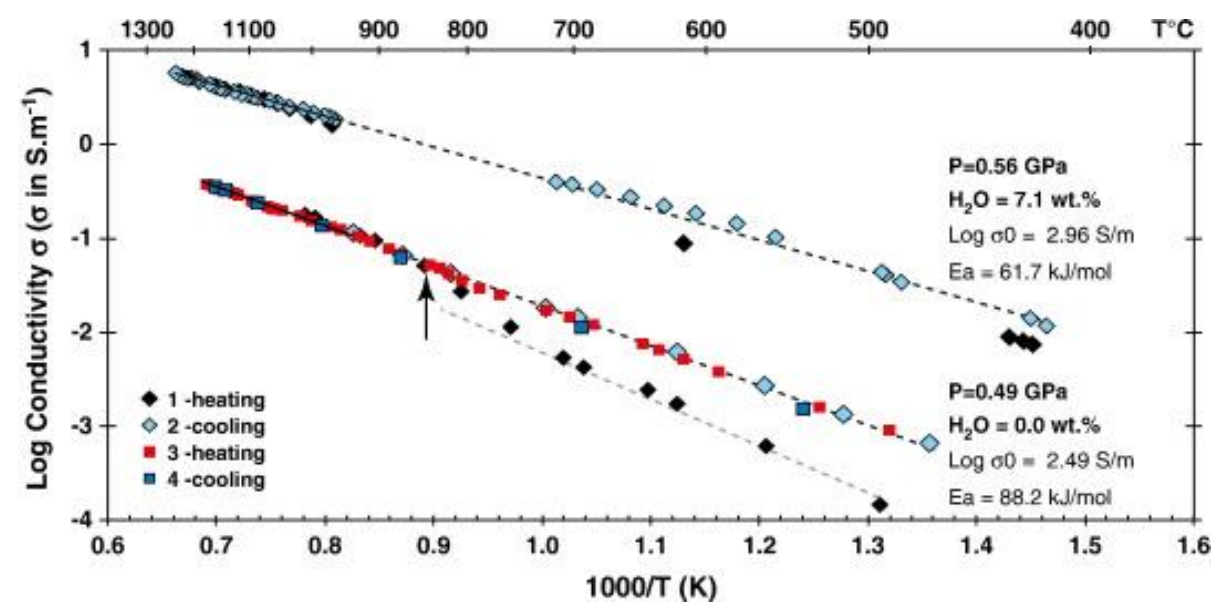

Fig. 5. : Arrhenius diagram of the electrical conductivity of UTU41B-0e and UTU41B-7c versus $1 /$ Temperature $(\mathrm{K})$ along heating and cooling paths. The black arrow indicates the temperature at which the conductivity is reproduced during the next temperature paths. The solid line is the fit of experimental data at temperature higher than $950{ }^{\circ} \mathrm{C}$. See the text for details. 


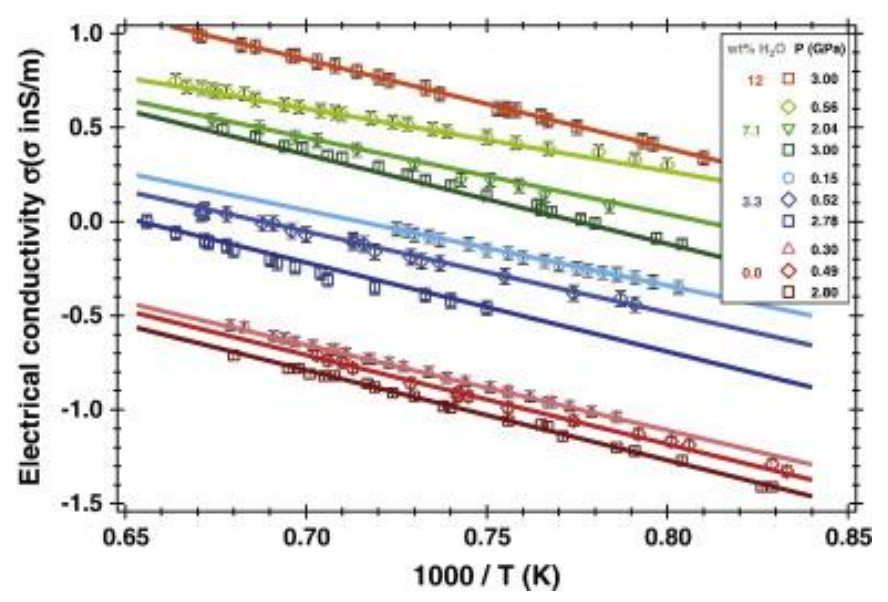

Fig. 6. : Arrhenius diagram of the electrical conductivity of dry and hydrous dacitic melts versus 1000/Temperature in K (open symbols). The legend indicates the water contents of the dacite (numbers in color, refer to the online version) and the pressure of the experiments (black number). The fits of the models for dry and hydrous dacitic compositions at various pressures using Eqs. (1), (5) and (7) and the fitting values in Table 3 are represented by curves with the same color code.
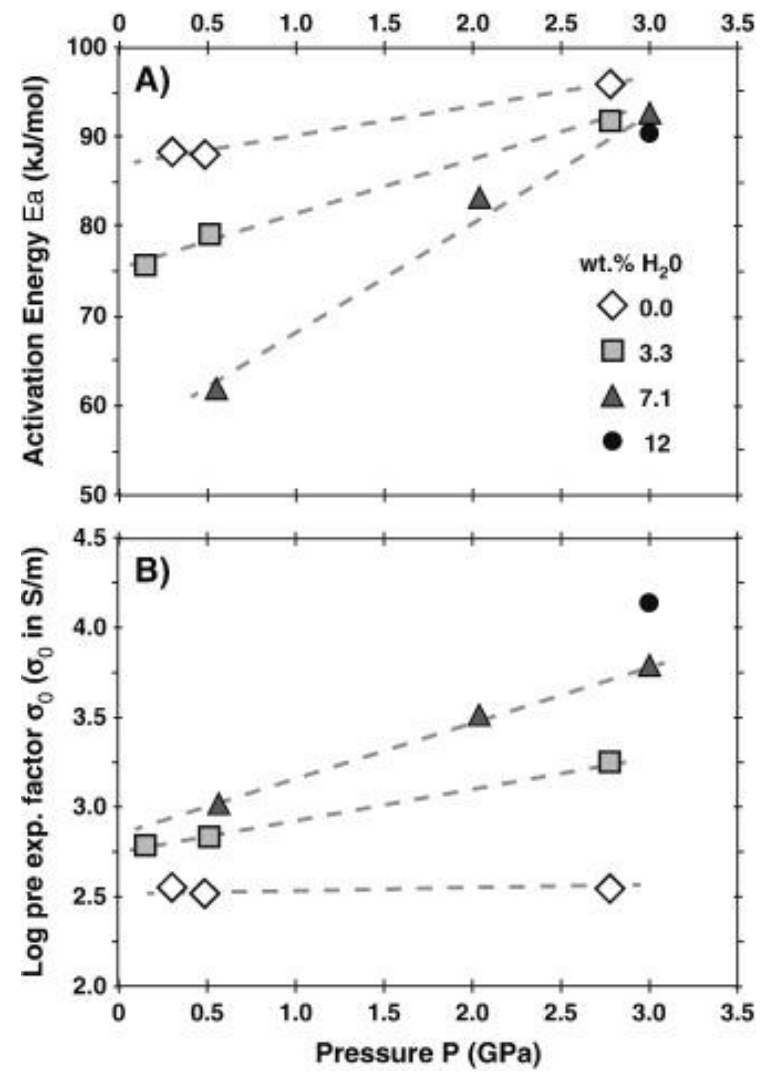

Fig. 7. : Activation energy (A) and pre-exponential factor (B) versus the pressure. Same legend in $\mathrm{A}$ and $\mathrm{B}$. 


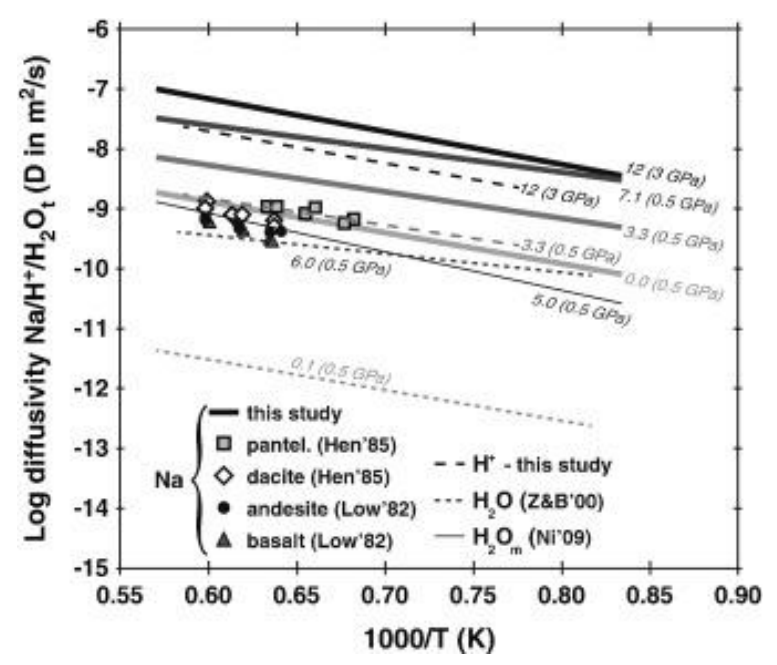

Fig. 8. : Na, $\mathrm{H}^{+}$diffusivities determined from electrical conductivity measurements for the four dacitic melts with different water contents (number on the right of curves), and $\mathrm{H} 2 \mathrm{O}$ diffusivity reported by Zhang and Behrens (2000). The Na diffusivities are compared with values from the literature (Lowry et al., 1982 and Henderson et al., 1985).

Table 3.

Fitted parameters of the electrical model of dry and hydrous dacitic melts.

$$
\begin{aligned}
& \text { Parameter Value } \\
& a-0.064 \\
& \sigma_{0} \quad \text { dep } 1.06 \mathrm{E}-05 \\
& \text { d 2.49E-05 } \\
& \begin{array}{rr}
H & \mathrm{e}-6146 \\
\mathrm{Ea} & \mathrm{f} 88,440
\end{array} \\
& \Delta V \quad \mathrm{~g} 0.176 \\
& \text { h } 0.388
\end{aligned}
$$



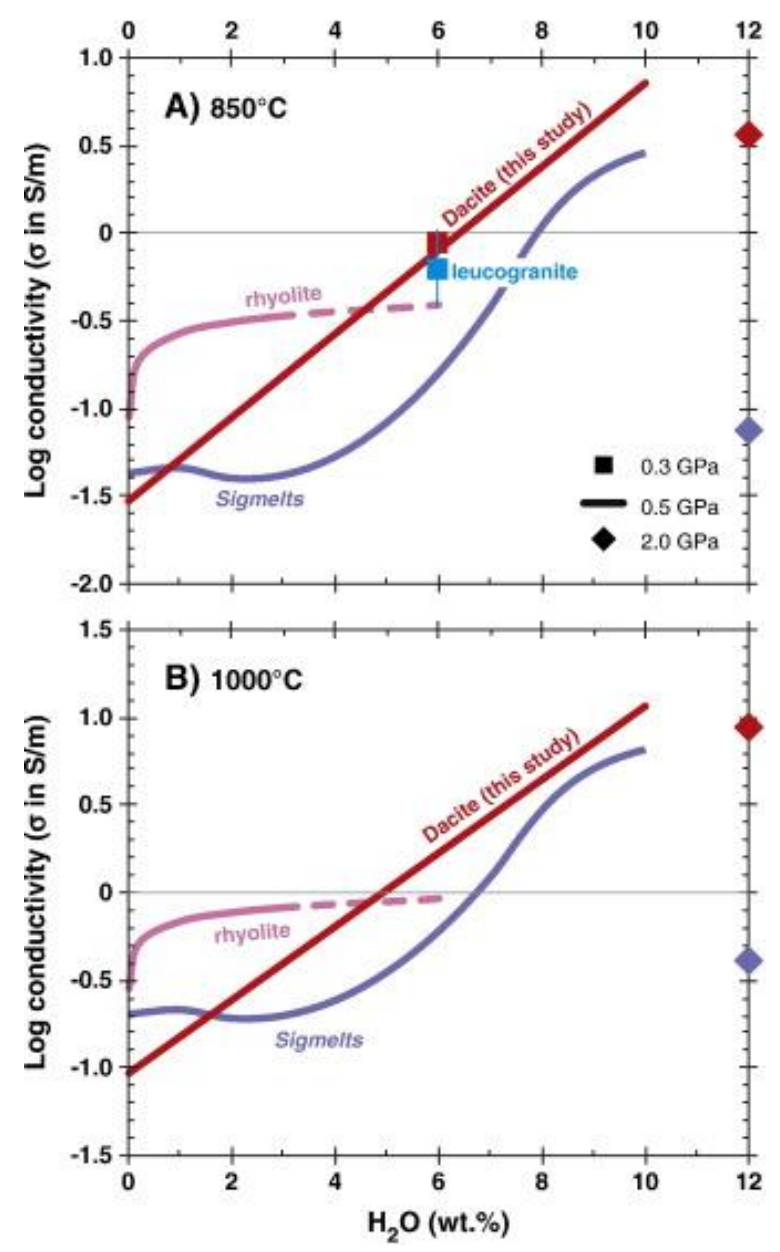

Fig. 9. : Log of conductivity versus water content of the dacite at $850(\mathrm{~A})$ and $1000{ }^{\circ} \mathrm{C}(\mathrm{B})$ compared with data from the literature. Rhyolite is from Gaillard (2004), Sigmelts is a model simulating the dacitic composition (Pommier\& Le Trong, 2011) and metapelite is from Hashim et al. (2013). 

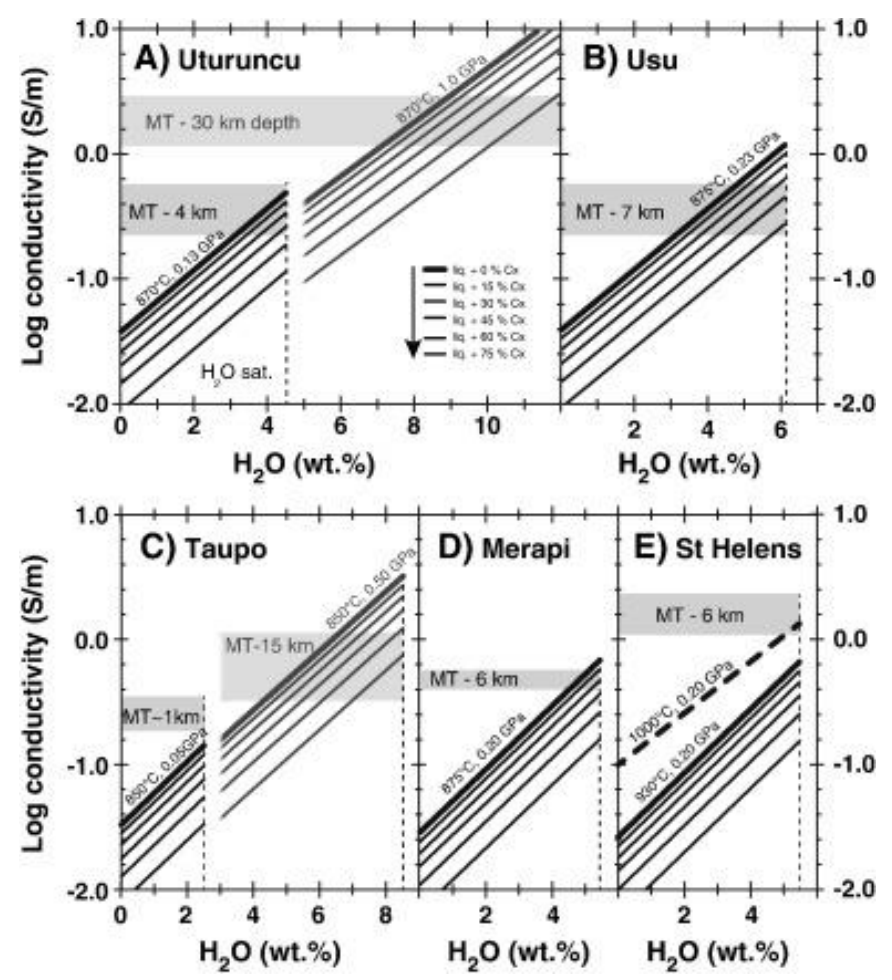

Fig. 10. : Electrical conductivities of Altiplano-Puna Magma Body (Bolivia, A), Usu (Japan, B), Taupo (New Zealand, C), Merapi (Indonesia, D) and St Helens (Washington state, E) areas from magnetotelluric survey (gray rectangles) and corresponding conductivities from the model. Conductivities are represented until water saturation $\left(\mathrm{H}_{2} \mathrm{O}\right.$ sat. $)$ estimated from the conductive body depth. Solid lines are calculated conductivity from the model of this study, the thick and thin ones being respectively the melt and a mixture of a melt + crystal conductivities. See the text for details.

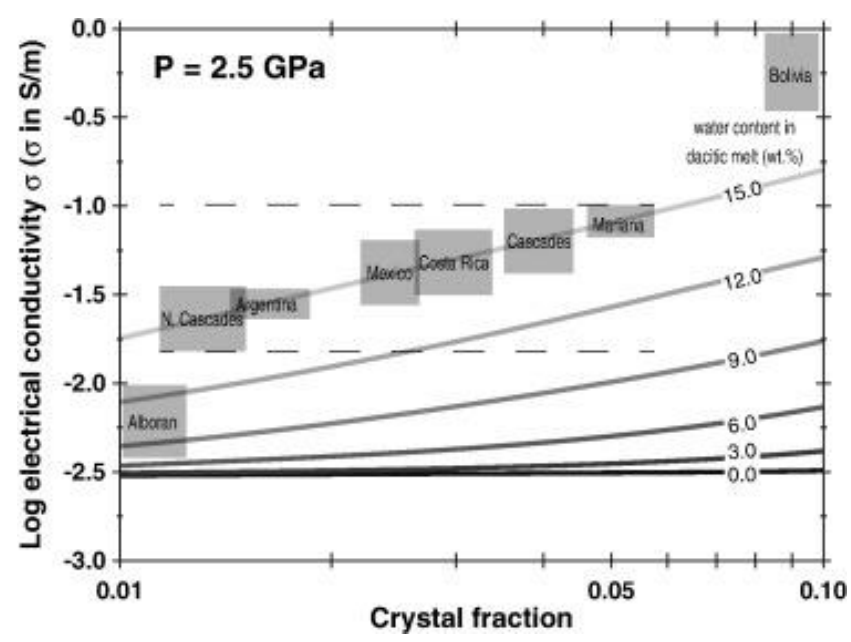

Fig. 11. : Electrical conductivity of the cold mantle wedge percolated by a small fraction of dacite. MT data are not specific to any particular melt fraction and come from Booker et al. (2004) (Argentina), Soyer and Unsworth (2006) (Northern Cascades), Jodick et al. (2006) (Mexico), Patro and Egbert (2008) (Cascades), Brasse et al. (2009), Worzewski et al. (2011) (Costa Rica), Matsuno et al. (2010) (Mariana) and Rosell et al. (2011) (Alboran). 